Studia Slavica Savariensia 2016. 1-2. 221-227

DOI: $10.17668 /$ SSS.2016.1-2.221

\author{
Ljubica Josić \\ (Zagreb, Hrvatska)
}

\title{
POETIZMI U JEDNOJEZIČNIM OPĆELEKSIČKIM RJEČNICIMA HRVATSKOGA JEZIKA
}

\begin{abstract}
In this paper we research the scope of the lexical group specific to the poetical substyle of literary-artistic functional style in one-language general lexic Croatian dictionaries. We analyse stylistic reference points assigned to that part of the stratified lexis while using specific dictionary entries to problematise the division of the poetical lexis from the expressive lexis, then from the outdated lexis and the lexis of the more expansive literary language. The goal of the paper is to list poetic words in all researched dictionaries and analyse them, as well as point out lexicographic difficulties connected with multi-type stylistic denotation of a lexis with limited use.
\end{abstract}

Keywords: Croatian language, stylistic stratification, loaded words, poetisms, lexicography

\section{Uvod}

Prije popisa $\mathrm{i}$ analize stilskih odrednica te semantičkoga polja poetizama $\mathrm{u}$ jednojezičnim općeleksičkim rječnicima hrvatskoga jezika valja utvrditi što su poetizmi. Naziv poetizam, prema SIMEONU (1969: 73) proteže se na nekoliko značenja - "pjesnički element«, "pjesničko obilježje« i »pjesničku riječ ili izraz«, a poetski leksik obuhvaća »pjesnički fond riječi, rječnik pjesničkoga jezika«. Poetizmi ili »leksemi karakteristični za pjesnički podstil«, kako navodi SAMARDŽIJA (1995: 42), rijetko su u uporabi izvan toga podstila književnoumjetničkoga funkcionalnog stila, poput primjera Bogomajka, cjelov, djeva, grôce, krin, nebesan, plam, potiti (se), sanak, sânja (sânje), srdašce, veličajan. Govoreći o leksičkim razlikama između funkcionalnih stilova i ilustrirajući poetizme na sličnim primjerima, cjelov, djeva, kam, plam, sanak i srdašce, FRANČIĆ, HUDEČEK i MIHALJEVIĆ (2005: 293) ističu da je »književnoumjetnički funkcionalni stil na leksičkoj razini obilježen poetizmima, razgovorni stil standardnoga jezika kolokvijalizmima, a razgovorni stil koji ne pripada standardu žargonizmima, publicistički stil žurnalizmima, administrativni stil obilježen administrativizmima, a znanstveni znanstvenim nazivima (terminima)《. U prepoznatljivu leksiku pjesničkoga podstila uočljiva su karakteristična tvorbena i stilska obilježja jer dio poetizama sadržava apokopu, figuru dikcije, koja prema BAGIĆU (2012: 58-9) podrazumijeva skraćivanje osnovne riječi, najčešće »izostavljanjem glasa, 
sloga ili slogova na kraju riječi«, što se može prepoznati u leksemima kâm $\leftarrow$ kämēn, plâm $\leftarrow$ plämēn, prâm $\leftarrow$ prämēn, tj. u »riječima čija pojava automatski asocira na pjesništvo«. Toj skupini poetizama može se pridodati i leksem stûd $\leftarrow$ stüdēn, u kojem se također uočava opisan tvorbeni i stilski postupak i u kojem se po istome uzorku mijenjaju naglasna obilježja, te leksem grûd $\leftarrow$ grûdi u kojem u odnosu na osnovnu riječ nije došlo do naglasnih promjena. Apokope ilustriraju jedan od načina stvaranja leksičkih, tvorbenih i stilskih posebnosti u umjetničkome mediju gdje do osobita izražaja dolaze govorne vrjednote i u kojem je tvorbeni proces skraćivanja osnovne riječi, uz dugosilazni naglasak, uvjetovan i ritamskim obilježjima, tj. versifikacijskim zahtjevima pjesničkoga govora.

U kojem opsegu jednojezični rječnici hrvatskoga jezika obuhvaćaju poetizme i na koji način su leksemi svojstveni pjesničkomu podstilu ondje obrađeni ovisi o više čimbenika: opsegu rječnika, rječničkome korpusu, ciljanoj recipijentskoj skupini, pojedinom obrađivačevu pristupu. Ipak, kako je u ovome istraživanju obuhvaćen korpus općeleksičkih rječnika koji uključuju funkconalnostilski leksički presjek, polazi se od činjenice da je svima njima zajedničko, uz središnji popis općega leksika, uključivanje funkcionalno raslojenoga leksika, pa tako i poetizama. Stoga se u radu analiziraju razlike u zastupljenosti poetizama i njihovoj obradbi u općeleksičkim jednojezičnicima hrvatskoga jezika, s posebnim osvrtom na poetizmima pridružene stilske odrednice. Cilj je rada popisati i analizirati sve poetizme u tim rječnicima, kao i uputiti na leksikografske poteškoće vezane uz viševrsno stilsko označivanje uporabo ograničena leksika, posebice zato što se o rječničkim poetizmima u kroatistici, izuzev uzgred, dosad nije pisalo.

\section{Rječnički članak: poetizmi i stilske odrednice}

Izradba općeleksičkih rječnika temelji se na kritičkome izboru heterogena korpusa da bi izbor rječničkih natuknica bio što reprezentativniji. Pritom se primjenjuje kriterij čestoće uporabe leksema, što je osobito važno za obuhvaćanje općega leksika, te kriterij približno podjednaka zahvaćanja svih leksičkih slojeva. Zbog toga je pred leksikografima težak zadatak izbora primjerene, raznovrsne građe, a koja, između ostaloga, ako se teži funkcionalnostilskoj reprezentatnosti, obuhvaća i pjesničke tekstove različitih autora. Iz njih se izdvajaju leksemi koji su karakteristični za pjesnički podstil ili za pjesnički jezik te izrađuju popisi koji postaju dijelom abecedarija, potom ulaze u leksikografsku obradbu. Uz gramatičke, etimološke, terminološke ili strukovne i značenjske odrednice, važna sastavnica rječničkoga članka je stilska odrednica kojom se označuje pripadnost leksema određenomu stilskomu sloju. U slučaju (funkcionalno)stilskoga označivanja leksema kao dijela poetskoga leksika, u svim jednojezičnicima hrvatskoga jezika rabi se kratica poet. u značenju »poetizam«, »poetično« ili »poetski«.

Valja imati na umu da se stilske odrednice jednim dijelom prepleću, posebice one kojima se određuje pripadnost »jezičnomu sloju« (BABIĆ 1981: 
80), među kojima je i odrednica poet., a koje se zbog visokoga stupnja ekspresivnosti u određenom broju slučajeva mogu smatrati i ekspresivnim odrednicama. U tome kontekstu može se primijetiti leksikografsko kolebanje u bilježenju stilske pripadnosti leksema präskozōrje, smïrāj i stüdēn koji su gdjegdje atribuirani poetskom pripadnošću, a u većini leksikografskih opisa obilježeni samo oznakom ekspresivnosti. Umrežavanje je stilskih odrednica zamjetno u onom dijelu leksika u kojem je riječ o odmilicama te u onim leksemima kod kojih, uz ekspresivne, gramatičke odrednice mogu potencijalno sugerirati poetske vrijednosti kao kod umanjenica (u kontekstu je tih zamjedbi ilustrativan leksem dának koji je odmilica i umanjenica, a može imati i poetsku vrijednost). Sve to navodi na zaključak da stilsko označivanje poetizama podrazumijeva istovremeno smještanje leksema u sustav različitih tipova stilskoga određivanja, što može dovesti do nizanja stilskih odrednica, posljedično i do nepodudaranja leksikografskih opisa u tom dijelu rječničkih članaka: „Odrednice koje govore o funkciji i stilskoj vrijednosti riječi ili jedinice jezika ne idu u red objektivnih datosti u jeziku (kao što je postojanje sedam padeža; slaganje u rodu, broju i padežu; postojanje točnog broja glagolskih vremena itd.). Odrednice često upućuju na kontekste i situacije o kojima ovise. Podliježu relativiziranju u vremenu i prostoru (npr. generacijski, pa regionalno, lokalno i sl.). Zato se nerijetko preklapaju i kombiniraju u leksikografskom opisu« (ANIĆ 1998: 1426).

U velikom broju rječničkih poetizama riječ je o jednoznačnosti i opoziciji stilske obilježenosti i stilske neobilježenosti ili neutralnosti sa stilskom odrednicom kao razmeđom kojom se uravnotežuje lijeva i desna strana rječnika te ona funkcionira kao poveznica između općeuporabnoga, stilski neutralnoga leksika (s desne strane) s poetizmima kao funkcionalno ograničenim leksikom s lijeve strane (osim ako određeni leksikografski pristup uz stilsku oznaku donosi i širu definiciju). Time je rječnički članak zatvorena mikrostruktura: u njemu se povezuje opći leksik s funkcionalnim posebnostima i vice versa, te se u tome povezivanju nakon stilske oznake navodi leksem bez stilske obilježenosti, bez stilskoga naboja, stilski neutralna uporaba. U manjem je broju rječničkih poetizama oznaka poetskoga pridružena nekomu od više značenja pojedinih leksema te se u takvoj semantičkoj razvedenosti poetska značenja kao funkcionalno raslojena ili stilski obilježena obično navode nakon definicija neutralnoga i terminologiziranoga značenja.

\section{Poetizmi u jednojezičnim općeleksičkim rječnicima hrvatskoga jezika}

U ovome su radu istraženi poetizmi u jednojezičnim rječnicima hrvatskoga jezika: Rječniku hrvatskoga jezika gl. urednika J. ŠONJE (2000.), Rječniku hrvatskoga jezika (1998.) i Velikome rječniku hrvatskog jezika V. ANIĆA (2003.), Školskome rječniku hrvatskoga jezika M. BIRTIĆ i sur. (2012.) te Velikome rječniku hrvatskoga standardnog jezika gl. urednice Lj. JOJIĆ (2015.). Napominjemo da uzimamo u obzir samo određene dijelove rječničkoga članka: natuknicu ili lemu, stilske i potencijalno stilske odrednice 
te definiciju, u nekim slučajevima, ovisno o tipu natuknice, dio raslojena semantičkoga polja, sveze riječi, podnatuknice i bliskoznačnice, čime ispuštamo oznaku poet., a zanemarujemo gramatičku paradigmu, naglasnu dubletu, primjere i dr.

U Rječniku hrvatskoga jezika gl. ur. J. ŠONJE (2000.) sadržano je petnaest poetizama: bòjak (»boj«), bôlan (u zadnjem navedenom značenju »bolestan«), bôlnīk (u dvama značenjima: »bolesnik« i »onaj koji trpi bol; trpljenik, patnik«), dának ${ }^{l}$ (uz odrednice umanj $i$ umilj »dan«), domája (»domovina, zavičaj, postojbina«), grûd (»grudi, prsa«), kâm (»kamen«), lúna (»Mjesec«), pjësan (u prvom navedenom značenju - »pjesma«), pjësmotvor (»pjesničko djelo; pjesma, spjev«), plâm (»plamen«), praskòzōrje (»u prvom navedenom značenju - »osvit, zora «), püpoljak (u prvom navedenom značenju - »djevojčica koja tek počinje spolno zreti«), tmä (»tama«) i vësna (u značenju "proljeće« kao podnatuknica mitološkoga naziva Vesna). Riječ je većinom o imenicama (unutar imenične skupine i trima apokopama: grûd, kâm, plâm), u jednom slučaju o pridjevu (bôlan), ostale vrste riječi nisu zastupljene. Osim odrednice pripadnosti poetskomu podstilu, samo jedan leksem ima ekspresivne i gramatičke oznake koje bi se potencijalno mogle smatrati i stilskima $\left(\right.$ dának $\left.^{l}\right)$. Sličan je primjer leksem nòćca, koji je obilježen kao umanjenica i umiljenica od riječi nố, a za koji, prema pojavnicama u knjižnome potkorpusu Hrvatske mrežne riznice Instituta za hrvatski jezik i jezikoslovlje (riznica.ihjj.hr), također možemo tvrditi da pripada poetskomu leksiku. U odnosu na rječničke natuknice poetskoga leksika ostalih rječnika, u ovom popisu poetizama sadržan je leksem koji se drugdje pretežno smatra dijelom ekspresivnoga leksika (praskòzōrje u značenju »zora, osvit«). Leksemi cjèlov i cjelívati, koji se obično pridružuju stilski obilježenu leksiku, tj. vremenski raslojenu leksiku, gdjegdje i poetskomu leksiku, ovdje pripadaju neutralnu leksičkom fondu hrvatskoga jezika.

U Velikome rječniku hrvatskoga jezika V. ANIĆA (2003.) poetizmi su izrazito malena leksička skupina koja obuhvaća svega pet leksema, od toga dva pridjeva i tri imenice - bäjoslōvan (u trećem navedenom značenju - »koji počiva na mašti«, s pridodanim bliskoznačnicama fabulozan i fantastičan), plâm (uz odrednicu ekspresivnoga »usp. plämēn«) pláman (»v. plàmen«), rûj ${ }^{l}$ (»rumena, ružičasta boja; rumenilo«), tmä (»tama«). Dio leksema koji u Rječniku hrvatskoga jezika (2000.) ima odrednicu poetskoga, u ovome rječniku ima više stilskih odrednica: odrednice retoričkoga i jezika književnosti (leksemi bôlnīk i domája), odrednice ekspresivnoga i knjiškoga leksika (kâm u prvom navedenom značenju »kamen«), a po jednu stilsku odrednicu leksemi vësna (»knjiš. naziv za proljeće«) i stûd (»ekspr., v. studen«). Leksem bójak, primjerice, nosi više gramatičkih odrednica: hipokoristik je i deminutiv od leksema boj, kojeg je naznačana dvovrsna stilska obilježenost (ekspresivno i jezik književnosti), a taj isti tip stilske obilježenosti sadržan je i u leksemima cjèlov (»jez. knjiž. ekspr. poljubac«) i cjelívati (»ekspr. jez. knjiž. ljubiti«). U usporedbi s poetizmima u Rječniku hrvatskoga jezika V. ANIĆA (1998., treće, 
prošireno izdanje), zanimljivo je primijetiti nekoliko preobrazbi njihova leksikografskoga opisa. Uz objašnjenje odrednice poetski, u trećem se izdanju navodi da je riječ o »pjesničkom sredstvu« i o »užem pojmu od jezika književnosti« (str. 1431.). U skladu s tim omeđenjem, leksemi koji nose oznaku poetizma su: djéva (»jez. knjiž. hip., djevojka«), plâm (»ekspr., v. plämēn«), pláman (»v. plàmen«), vësna (»proljeće«), iz čega je vidljivo da neki leksemi, poput leksema djéva, uz odrednicu pjesničkoga sredstva nosi i širu odrednicu jezika književnosti, u ovom slučaju i gramatičku odrednicu hipokoristika. Razvidno je da su poetizmi kao leksička skupina u Velikome rječniku hrvatskog jezika V. ANIĆA (2003.) prošireni semantičkim razgranjivanjem kao u slučaju leksema bajoslovan (koji je u izdanju iz 1998. godine imao dva značenja: »1. bajan; 2. kao u bajci «) te dodavanjem leksema kojih nije bilo u abecedariju izdanja iz 1998. (leksemi tmä i $r \hat{u} j^{l}$ ). Popis je poetizama u odnosu na izdanje iz 1998. dijelom je i sužen jer je leksem vësna, umjesto oznakom poet., obilježen oznakom knjiš. u značenju »knjiški leksem«, a leksem rûj homonimijski razgođen na dvije natuknice - nakon botaničkoga naziva navodi se leksem uz koji su stilske odrednice jezika književnosti i ekspresivnoga nadomjestile odrednicu poetski.

U Školskome rječniku hrvatskoga jezika M. BIRTIĆ et al. (2012.), čiji temeljni rječnički korpus sačinjavaju udžbenički tekstovi, sadržano je četrnaest poetizama: bèsjeda (»tekst koji se izgovara u kakvoj prigodi«), cjèlov (»zast. v. poljubac«), pêst (»dlan s prstima u stisnutome položaju«), pöviše (»1.v. iznad 2. v. nad«), sánja (»1. niz manje ili više povezanih slika i događaja koje tko vidi dok spava 2. pren ono na što se često misli, o čemu se mašta ili što se želi ostvariti, neostvarena želja«), smïrāj (»vrijeme između zalaza Sunca i početka noći«), snïti (u prijelaznome značenju »imati san ili snove tijekom spavanja« te neprijelaznome značenju » odmarati se zatvorenih očiju i bez svijesti o vanjskim zbivanjima«), snivānje (u trima značenjima: »imanje sna ili snova tijekom spavanja«, "prepuštanje mašti u budnome stanju, zamišljanje onoga što bi se željelo ostvariti« $\mathrm{i}$ »odmaranje zatvorenih očiju i bez svijesti o vanjskim zbivanjima««, snivati (u prijelaznome značenju »imati san ili snove tijekom spavanja i i neprijelaznome značenju "prepuštati se mašti u budnome stanju, zamišljati ono što bi se željelo ostvariti« i »odmarati se zatvorenih očiju i bez svijesti o vanjskim zbivanjima«), stùden (»koji ima veoma nisku temperaturu, koji je jako hladan«), stüdēn (»stanje prouzročeno niskim temperaturama zraka«), znämēn (u prenesenom značenju »ono čime je što obilježeno«), zvôn (»zvuk zvona«), žâl (»stanje onoga koji je žalostan, psihička patnja zbog nečega što se ne može promijeniti«). Među zastupljenim poetizmima glavnina je imenica, njih deset, potom slijede glagoli i pridjevi, a prijedlog pövišē, koji pripada općeneutalnomu leksiku u značenju »iznad čega«, »nad čim«, i obrađen je s pomoću normativne odrednice - uputnice na lekseme iznad i nad, vjerojatno je omaškom okvalificiran kao poetizam. Leksem cjèlov, uz pripadnost poetskomu leksiku, ima odrednicu zastarjeloga sloja, dok su, očekivano s obzirom na rječnički korpus, popisani i obrađeni »rjeđi« poetizmi 
(leksemi zvôn i žâl). Neki su leksemi, koji inače pripadaju neutralnomu fondu, označeni kao poetizmi (smïrāj, stùden, stüdèn, znämēn u prenesenome značenju »ono čime je što obilježeno«). Uz leksem znämēn (poetski i preneseno značenje), leksem cjèlov također ima pridodane dvovrsne stilske oznake (poetski i zastarjelo), dok ostali navedeni leksemi nose isključivo odrednicu poetske pripadnosti.

Veliki rječnik hrvatskoga standardnog jezika (2015.) gl. urednice Lj. JOJIĆ obuhvaća petnaest poetizama: bïstrica (u dvama značenjima, »bistra voda« i »ono što je bistro (opisna riječ uz imenicu)«, domája (»domovina, postojbina, zavičaj «), pêst (»šaka«), pjësan (u drugome navedenom značenju - »pjesma«), plâm (»plamen $\left.{ }^{1} \ll\right)$, pláman (»plamen $\left.{ }^{2} \ll\right)$, plôv (u prvome navedenome značenju - "plovidba«), rûj ${ }^{l}$ (»ružičastocrvenkasta boja«), snïti (u prijelaznome i neprijelaznome značenju »sanjati«), stûd (»studen $\left.{ }^{1} \ll\right)$, südēn ${ }^{l}$ (u dvama značenjima: "vremenske prilike $\mathrm{s}$ niskim temperaturama zraka« $\mathrm{i} u$ prenesenome značenju »osjećaj jeze«), stùden ${ }^{2}$ (»koji je vrlo hladan«), tmä (»tama«), tmüo (u dvama značenjima »koji je tmuran« i »koji je mukao, dubok i prigušen, koji nije zvonak (o ljudskom glasu)«, tmüša (»tama«), te svezu biti bolan u značenju »biti bolestan « uz leksem bôlan. Riječ je o deset imenica, tri pridjeva i jednome glagolu. Svi imaju samo jednu stilsku odrednicu, osim leksemâ pjësan koji okarakteriziran prvo kao zastarjelica, potom u jednome od značenja kao poetizam (»pjesma«) te leksema stûd uz koji je navedena i odrednica prenesenoga značenja. U odnosu na poetizme iz ostalih analiziranih rječnika, u ovom su rječniku u tu skupinu ubrojeni i oni leksemi koji su drugdje nosili oznaku ekspresivnosti (primjerice pridjev tmüo u dvama značenjima i imenica tmüša u značenju »tama«). Neobično je atrbuiranje leksema plôv poetizmom (u prvom navedenom značenju »plovidba «), dok su kao knjiški izrazi označeni leksemi grûd, kâm (u prvom navedenom značenju »kamen«), bôlnīk, präskozōrje (u obama značenjima), sânja, vësna. Leksem cjèlov, primjerice, atribuiran je strukovnom odrednicom knjiž (književnost) te stilskom odrednicom zast (zastarjelica), a leksem smïrāj opisan kao dio stilski neutralana leksičkoga fonda hrvatskoga jezika.

\section{Zaključak}

Poetizmi kao dio uporabno ograničena leksika ili tzv. izama, ulazeći u rječnik, pokreću pitanje reprezentativnoga izbora, potom zahtijevaju stilsko određivanje, što u mnogim slučajevima, pokazuje provedena analiza, nije jednostavan zadatak, ostavljajući obrađivaču utjehu u relativno lako rješivoj desnoj strani, tj. jednostavnijem opisu semantema. Utvrđeno je da su poetizmi u jednojezičnim općeleksičkim rječnicima hrvatskoga jezika izrazito mala leksička skupina koja obuhvaća od svega nekoliko do ne više od dvadeset rječničkih natuknica. Gledano s morfološkoga aspekta, pokazano je da su poetizmi pretežno imenice i pridjevi, rjeđe glagoli, a druge vrste riječi, izuzev jedne iznimke, nisu zastupljene. Svi su poetizmi, s većim ili manjima odstupanjima, na desnoj strani rječnika podudarni (ovisno o tipu 
leksikografskoga opisa), a u mnogim slučajevima varijantni u atribuciji stilske pripadnosti. Kako je analiza pokazala, možemo tek uvjetno govoriti o skupini najfrekventnijih/ili najprepoznatljivijih leksičkih obilježja poetskoga jezika u istraženim rječnicima (izbor natuknica ovisi o nizu čimbenika, prvenstveno korpusu, ali i o obrađivačevoj procjeni) jer njihove stilske atribucije variraju od poetskoga leksika do jezika književnosti (uz, ovisno o natuknici, i neke druge stilske odrednice), pa se u skladu s tim i ustaljene predodžbe o tipičnim poetizmima u rječničkim korpusima mijenjaju u brojčanu korist leksema tipičnih za književnoumjetnički stil u cjelini.

\section{Literatura}

BABIĆ 1981 = BABIĆ S. Stilske odrednice u našim rječnicima // Jezik, 1981. № 3 . 79-91.

BAGIĆ 2012 = BAGIĆ K. Rječnik stilskih figura. Zagreb, 2012.

FRANČIĆ, HUDEČEK, MIHALJEVIĆ 2005 = FRANČIĆ A., HUDEČEK L., MIHALJEVIĆ. M. Normativnost i višefunkcionalnost u hrvatskome standardnom jeziku. Zagreb, 2005.

SAMARDŽIJA 1995 = SAMARDŽIJA M. Leksikologija s poviješću hrvatskoga jezika: udžbenik za 4. razred gimnazije. Zagreb, 1995.

SIMEON 1969 = SIMEON R. Enciklopedijski rječnik lingvističkih naziva. Zagreb, 1969.

\section{Izvori}

ANIĆ Vl. (1998). Rječnik hrvatskoga jezika. Treće, prošireno izdanje. Zagreb: Novi Liber, 1988.

ANIĆ Vl. (2003). Veliki rječnik hrvatskoga jezika. Prir. Ljiljana Jojić. Zagreb: Novi Liber, 2003.

BIRTIĆ M. et al. (2012). Školski rječnik hrvatskoga jezika. Zagreb: Institut za hrvatski jezik i jezikoslovlje - Školska knjiga, 2012.

JOJIĆ Lj, gl. ur. (2015). Veliki rječnik hrvatskoga standardnog jezika. Zagreb: Školska knjiga, 2015.

ŠONJE J. gl. ur. (2000). Rječnik hrvatskoga jezika. Zagreb: Leksikografski zavod Miroslav Krleža: Školska knjiga, 2000.

Hrvatska mrežna riznica. Dostupno na: riznica.ihjj.hr. 